Dicle Tıp Dergisi / Dicle Med J (2019) 46 (3) : 535 - 542

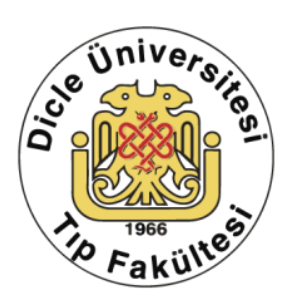

WWW.diclemedj.org

Original Article / Özgün Araştırma

\title{
Outcomes of Maximal Levator Resection Procedure in Cases of Congenital Myogenic Ptosis
}

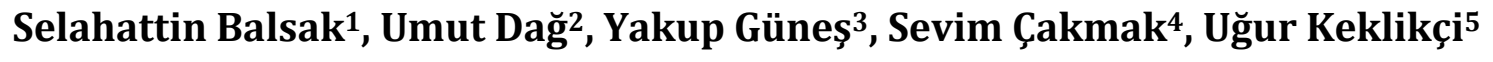 \\ 1 Diyarbakır Gazi Yaşargil Training and Research Hospital, Department of Ophthalmology, Diyarbakır, Turkey ORCID: 0000-0002-2269-474X \\ 2 Diyarbakır Gazi Yaşargil Training and Research Hospital, Department of Ophthalmology, Diyarbakır, Turkey ORCID:0000-0002-7866-7898 \\ 3 Batman Region Hospital, Department of Ophthalmology, Batman, Turkey ORCID:0000-0002-4745-0717 \\ 4 Dünya Göz Hospital, Department of Ophthalmology, Istanbul, Turkey ORCID:0000-0002-3199-7224 \\ 5 Dicle University Medical Faculty, Department of Ophthalmology, Diyarbakır, Turkey ORCID:0000-0003-2348-4856
}

Received: 27.05.2019; Revised: 02.07.2019; Accepted: 08.07.2019

\begin{abstract}
Objective: This study aimed to evaluate the outcomes of maximal levator resection in cases of congenital myogenic ptosis with poor levator function.

Method: Thirty-threeptotic eyelids of 30 cases undergoing maximal levator resection were retrospectively included. There were 18 male and 12 female cases. The mean age of the cases was $12.55 \pm 5.3$ years (range, 4-26 years). For all eyes, vertical palpebral aperture, margin reflex distance, levator functions, and upper eyelid crease height were measured. Ptosisseverity was "mild" when the eyelid elevation was $\leq 2 \mathrm{~mm}$; "moderate" when the eyelid elevation was $3 \mathrm{~mm}$; and "severe" when the eyelid elevation was $\geq 4 \mathrm{~mm}$. The mean age of the cases (18 males and 12 females) was $12.55 \pm 5.3$ years (range, $4-26$ years).

Results and Conclusion: The mean ptosis severity (vertical palpebral aperture) was $5.136 \mathrm{~mm}$ preoperatively and $0.818 \mathrm{~mm}$ at the postoperative Month $3(\mathrm{p}<0.001)$. Surgical outcomes were successful in 26 eyes $(78 \%)$, satisfactory in 4 eyes (12\%), and unsuccessful in 3 eyes (9\%).Conclusively, successful outcomes were obtained after maximal levator resection in ptosis cases with poor levator functionin most of casses.
\end{abstract}

Keywords: Acquired ptosis, congenital myogenic ptosis, levator function, maximal levator resection, surgical success.

DOI: $10.5798 /$ dicletip.620581

Yazışma Adresi / Correspondence: Selahattin Balsak, Memorial Dicle Hastanesi, 21010, Kayapınar, Diyarbakır, Turkey

e- mail: selahattinbalsak@gmail.com 


\section{Konjenital Miyojenik Pitoz Vakalarında Maksimum Levator Rezeksiyonu Prosedürünün Sonuçları}

\section{Öz}

Amaç: Bu çalışmanın amacı, düşüklevator fonksiyonlu konjenital pitozis olgularında maksimum levator rezeksiyonu sonuçlarını değerlendirmektir.

Yöntemler: Retrospektif olarak maksimum levator rezeksiyonu yapılan 30 olgunun 33 pitotik gözkapağı çalıșmaya

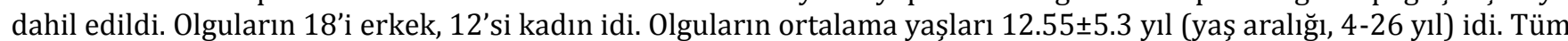
gözlerde dikey gözkapağı açıklığı, marjin reflex uzaklığı, levator fonksiyonu, üst gözkapağı cilt kıvrımı yüksekliği ölçüldü. Pitozis derecesi, gözkapağı hareketi $\leq 2 \mathrm{~mm}$ olduğunda 'hafif', $3 \mathrm{~mm}$ olduğunda 'orta' ve $\geq 4 \mathrm{~mm}$ olduğunda 'ağır' olarak kaydedildi.

Sonuç ve Yorum: Ortalama pitozis derecesi (dikey gözkapağı açıklığı) ameliyat öncesi $5.136 \mathrm{~mm}$, ameliyat sonrası 3. ayda $0.818 \mathrm{~mm}$ idi $(\mathrm{p}<0.001)$. Yirmialtı gözde (\%78) cerrahi sonuçlar başarıll, 4 gözde tatmin edici (\%12) ve 3 gözde başarısız (\%9) idi. Sonuç olarak düşük levator fonksiyonlu pitozis olgularının çoğunda maksimum levator rezeksiyonu cerrahisinde başarılı sonuçlar elde edilmiştir.

Anahtar kelimeler: Edinilmiş pitozis, konjenital miyojenik pitozis, levator fonksiyonu, maksimum levator rezeksiyonu, cerrahi başarı.

\section{INTRODUCTION}

Ptosis, unilateral or bilateral drooping of the upper eyelid, is the third most common eyelid disease after chalazion and entropion and results in cosmetic and functional problems ${ }^{1}$. Ptosis may lead to amblyopia; moreover, particularly relatively mild ptosis may cause obstruction in the upper visual field ${ }^{1,2}$. Ptosis can also cause psychological problems in children and young adults.

Ptosis can be classified in two groups as congenital and acquired. Abnormally developed levator muscle (myogenic dysgenesis) or innervation abnormalities are the main causes of congenital ptosis.A variety of neurologic disorders, muscle disorders, traumas, and defects in the levator aponeurosis may be listed among the causes of acquired ptosis ${ }^{3}$. Clinical features of ptosis, levator function, comorbid oculomotor disorders, and presence of other abnormalities of the eyelid and face play important roles in surgical approach ${ }^{4}$. The most common surgical techniques are frontalis suspension technique and levator muscle procedures. Frontalis suspension technique is used for patients with poor levator function while levator muscle procedure is performed for those with sufficient levator function ${ }^{3}$. Levator muscle procedures include levator advancement and levator resection. In addition to these, the Whitnall sling procedure, in which the levator aponeurosis up to the point of Whitnall's ligament is resected, the FasanellaServat procedure, which includes the removal of up to $3 \mathrm{~mm}$ of superior tarsus, conjunctiva, Müller's muscle, and levator, and the Müller's muscle conjunctival resection technique, which is the resection ofMüller's muscle and conjunctiva, are also used surgical techniques $^{2,3}$. In cases of ptosis with poor levator function, the most recommended surgical method is frontalis suspension technique; however, as it results in more complications compared with levator resection, Whitnall sling procedure can be considered in selected cases $^{5}$. Moreover, maximal levator resection can be a surgical alternative to frontalis suspension in cases with poor levator muscle function but having a safe profile (without factors hindering the eye closure, with 
good Bell's phenomenon, and with normal lachrymal gland function) ${ }^{6}$.

The aim of the present study was to evaluate the outcomes of maximal levator resection in cases of congenital myogenic ptosis with poor levator function.

\section{METHOD}

In this retrospective study, 33 ptotic eyelids of 30 cases of congenital myogenic ptosis whounderwent maximal levator resection in the Ophthalmology Clinic of Dicle University Medical Faculty between January 2009 and December 2009 or in the Ophthalmology Department of Diyarbakır GaziYaşargilTraining and Research Hospital between May 2010 and December 2017were evaluated. Before maximal levator resection procedure, written informed consents of all cases as well as parents of the cases were obtained. The study was approved by the Ethics Committee of Diyarbakır GaziYaşargil Training and Research Hospital.

Data of the patients were retrieved from the hospital files. Detailed medical history of each case, including the onset of ptosis, type of ptosis (congenital or acquired), duration of ptosis, previous surgical operations, traumas, pregnancy, allergic reactions, previously used medications, previous systemic diseases, comorbid symptoms (such as jaw movement dysfunctions, diplopia, dysphagia, fatigue), change in severity of ptosis during the day, family history, and photos taken before (if any), were examined.

All cases had undergone detailed ophthalmologic examinations, including measurement of bilateral visual acuity and bio microscopic measurement of anterior and posterior chamber. For both eyes, vertical palpebral aperture, margin reflex distance (MRD), levator functions, and upper eyelid crease height were measured using a millimeter ruler and recorded. Before maximal levator resection procedure, photographs of all cases were taken in a well-lit room while they were looking straight across, down, and up.

Ptosis severity was defined as the difference in vertical palpebral aperture between the ptotic and normal eyes in unilateral cases. In bilateral cases, ptosis severity was evaluated by assuming that the normal corneal diameter was $11 \mathrm{~mm}$ and that the normal upper eyelid covered the upper limbus by 1-2 $\mathrm{mm}$ (in which the normal vertical palpebral aperture was about $9 \mathrm{~mm}$ ). The severity of ptosis was considered "mild" when the eyelid elevation was $\leq 2 \mathrm{~mm}$; "moderate" when the eyelid elevation was $3 \mathrm{~mm}$; and "severe" when the eyelid elevation was $\geq 4 \mathrm{~mm}$.

\section{Surgical Procedure}

Surgical procedures were performed in two different study centers and all surgeries were performed by two experienced surgeons (SB and SSC), one surgeon at each center. Two surgeons used the same surgical procedure. Before the surgery, the upper lid crease was determined as symmetrical with the other eyelid crease and marked with surgical pen. For adult cases $(n=4)$, subconjunctival $2 \%$ lidocaine infiltration with 1-2 $\mathrm{mL}$ of epinephrine was administered through the incision line for local anesthesia. For child cases $(n=26)$, general anesthesia was performed. For bleeding control, 7 minutes were waited and intraoperative hemorrhage was controlled using bipolar cautery. Following the skin incision at the upper eyelid line previously marked on the upper lid crease, skin incision flaps were elevated from medial to lateral with the help of two forceps and orbicular muscle was dissected using the Westcott scissors from the tarsal plate. The tissues remaining on the anterior surface of the tarsal plate were removed and at least one-third of the tarsal plate was exposed. The orbital septum was horizontally opened and the connections between levator aponeurosis and 
preaponeurotic fat tissues were excided using blunt and sharp dissection (Figure 1).

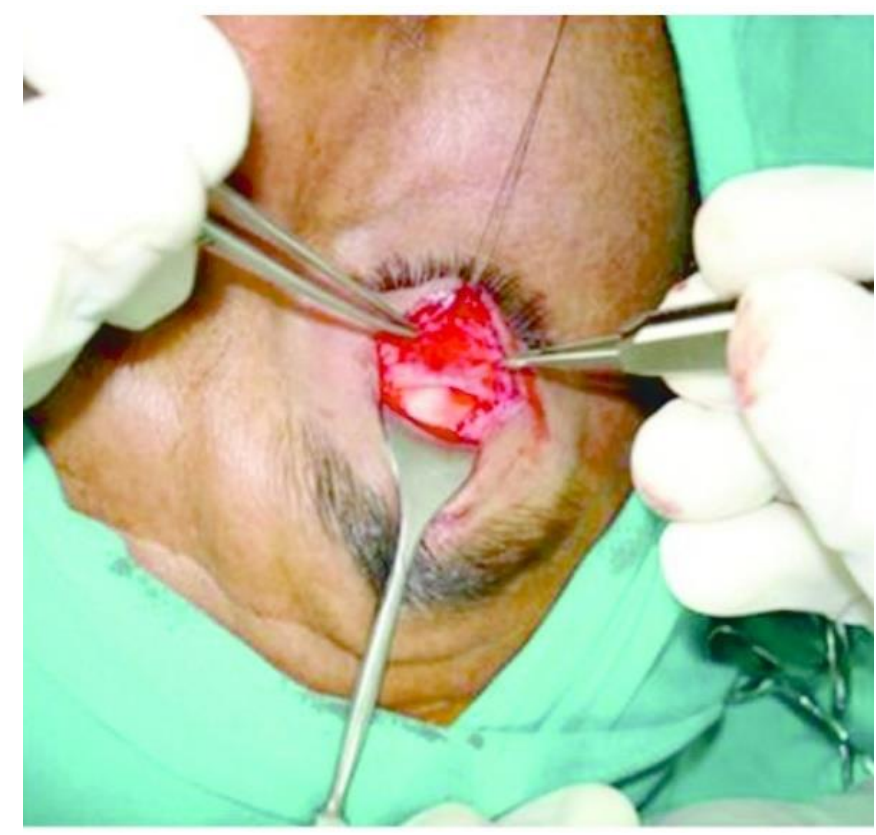

Figure 1. Exposing the levator muscle.

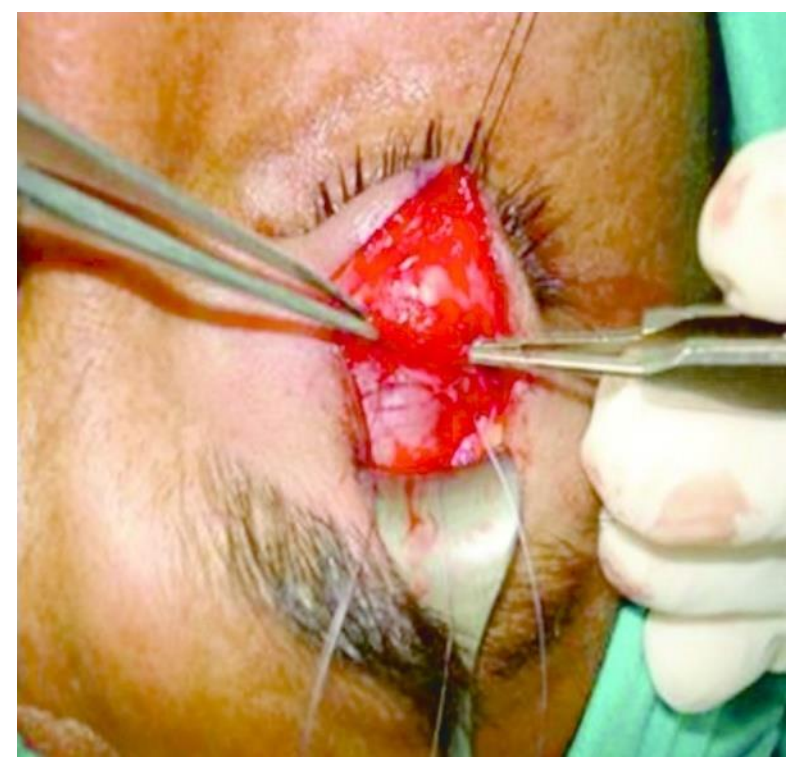

Figure 2. Insertion of the suture from the proximal of the Whitnall's ligament.

Then, the levator aponeurosis was dissected from the Müller muscle up to the Whitnall's ligament with sharp dissection. In order to determine the desired eyelid level, a temporary fixation sling suture was inserted from the tarsal plate with a knot using 6.0 polyglactin from the proximal of the Whitnall's ligament (Figure 2).The preaponeurotic fat tissues were removed using desmarres retractor. The eyelid level was checked and if the palpebral aperture was not sufficient, the temporary knot was untied and the suture was inserted from the upper point of the tarsal plate. If the palpebral aperture was wider than normal, the knot was again untied and reversely, the suture was inserted from the lower point of the tarsal plate.When the desired eyelid level was achieved, two additional sling sutures were inserted from the medial and lateral of the first suture within a same distance. An excessive improvement of 1.5-2 mm was aimed in cases considering the postoperative drooping. In order to establish eyelid creases, four additional sutures were inserted from the medial,nasal, and temporal of the lid through the lower skin incision flap, orbicular muscle, levator aponeurosis, upper skin incision flap. Finally, the skin was closed with running sutures. Frost suture were used in necessary cases and on postoperative day 1 , they were removed.

\section{Postoperative Care and Monitoring}

On the postoperative Day 1, all cases were administered prophylactic antibiotic ointments and eye drops. Lubrication with artificial tear drops was performed for early lagophthalmos and alteration in Bell's phenomenon7. All cases were asked to apply cold compression for 15 minutes in every hour for 3 days.

Regarding the outcomes of the surgery, the surgery was considered "successful" in cases with complete correction or residual ptosis $<1$ $\mathrm{mm}$ and symmetrically and cosmetically acceptable lid contours. However, the surgery was considered "satisfactory" in cases with residual ptosis of 1-2 $\mathrm{mm}$ and was considered "unsuccessful" in cases with residual ptosis $>2$ $\mathrm{mm}$. For possible early revisions, all cases were 
re-examined on the postoperative Day 3. The cases with lid edema were asked to apply cold compression for 5 more days. Lid heights, lid contours, upper lid crease, and other parameters were evaluated. On the postoperative Day 7, skin sutures on the lid were removed. Photos of the cases were taken at the postoperative Week 1 and Month 1 . The cases were re-examined on the postoperative Month 3 and Month 6 and then they were followed-up annually. The preoperative and postoperative photos of one case are shown in Figures 3 and 4.

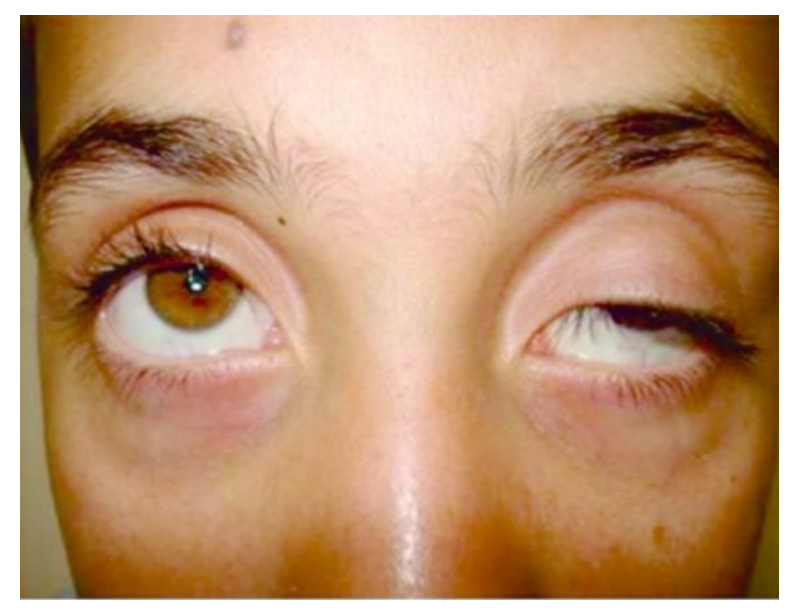

Figure 3. Preoperative image of the eyes a case.

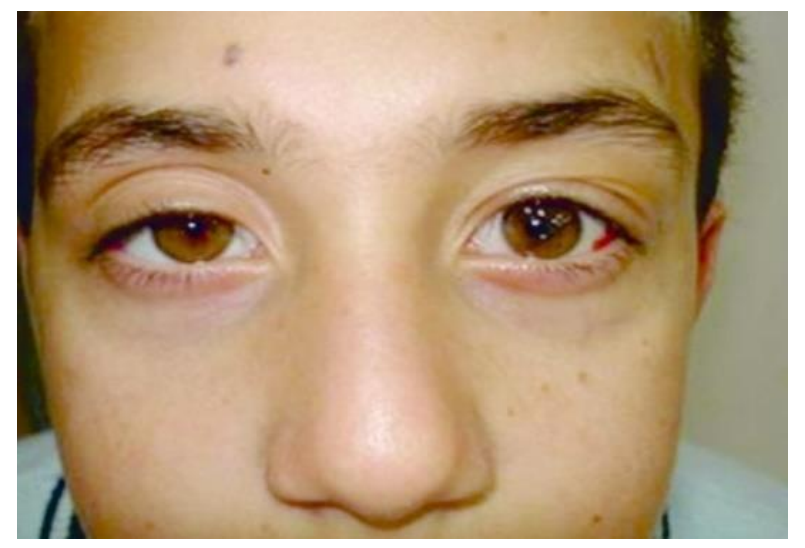

Figure 4. Postoperative image of the eyes a case.

\section{Statistical Analysis}

Descriptive statistics were expressed as numbers and percentages for categorical variables and as mean, standard deviation, median, and minimum-maximum for numerical variables. Statistical significance level was accepted as smaller than 0.05 of $p$ value.

\section{RESULTS}

Data of 30 congenital myogenic ptosis cases, of whom $18(60 \%)$ were males, were included and their mean age was $12.55 \pm 5.3$ years (range, 4-26 years). Levator function of all cases (33 eyes) was poor and 8 cases had bilateral ptosis. All cases had undergone maximal levator resection. Bilateral maximal levator resection was performed only for 3 cases. The median follow-up duration of the cases was 6 months (range, 3-9 months). The mean MRD value of all cases was $0.9 \mathrm{~mm}$ preoperatively and $3.7 \mathrm{~mm}$ postoperatively. Ptosis severity (vertical palpebral aperture) of all cases was $5.136 \mathrm{~mm}$ preoperatively and $0.818 \mathrm{~mm}$ at the postoperative month $3(\mathrm{p}<0.001)$.

According to the outcomes of the surgery, successful outcomes were obtained in 26 eyes (78\%), satisfactory outcomes were obtained in 4 eyes $(12 \%)$, and unsuccessful outcomes were obtained in 3 eyes (9\%). In these 3 cases with unsuccessful outcomes, preoperative levator function was $2 \mathrm{~mm}$. Moreover, intraoperatively, levator aponeurosis was atrophic, which was confirmed by the image of levator muscle (no additional pathological examination was performed) and fatty degeneration and underdevelopment of Whitnall's ligament were observed in the levator muscle. Frontalis suspension technique with silicon rod was performed in these 3 cases 6 months after the maximal levator resection and successful outcomes were obtained. Therefore, postoperative complication was observed in none of the cases. Only 1 case developed chalazion on the postoperative day 15 and improved with medical treatment. One case had excessive correction of $1 \mathrm{~mm}$ on the postoperative day 3 and the upper eyelid of the case was massaged (the upper lid was pulled 
down by holding the eyelashes, while the case was asked to look up) $3 \times 10$ daily and the eyelid level of the case returned to normal on the postoperative day ${ }^{7}$.

\section{DISCUSSION}

Surgical approach in ptosis is based on ptosis severity, levator function, amblyopia, age, and other physical features. Today, along with the well-known eyelid anatomy and better knowledge of etiology of ptosis, many surgical techniques have been described for correction of ptosis. Successful outcomes are obtained by surgical techniques which do not impair the anatomy, are easy, and provide predictable results. Among these surgical techniques, frontalis suspension is accepted as a gold standard in ptosis patients with poor levator function $(\leq 4 \mathrm{~mm}) .8$,9Maximal levator resection is generally preferred for the correction of ptosis when levator function is poor-to moderate $(>4 \mathrm{~mm}) .9$ However, there are still controversies among ophthalmologists regarding the surgical procedures for the correction of ptosis with poor levator function. Maximal levator muscle resection can be better than frontalis suspension in the correction of congenital ptosis as it can provide cosmetically better outcomes and less postoperative complication rate.10 Similarly,in the study by Gazzola et al.,5 the complication rate was reported as $3.1 \%$ in levator resection while it was $22.2 \%$ in frontalis suspension. In the present study, which included congenital myogenic ptosis cases undergoing maximal levator resection, no postoperative complication was observed as well. Only 1 case developed chalazion on the postoperative Day 15 and improved with medical treatment. Excessive correction of eyelid and lagophthalmos are major complications following surgical treatment of ptosis. In the present study, excessive correction (1 $\mathrm{mm}$ ) was obtained only in 1 case on the postoperative Day 3 and the eyelid level of the case returned to normal on the postoperative Day 7 .
It is an important advantage that maximal levator resection can be performed under local anesthesia in adult patients. Thus, levator mobility is not disturbed and lid level is more easily adjusted, which increases postoperative success.6In the present study, local anesthesia was performed in 4 adult cases and their lid levels were observed to return to ideal levels postoperatively.

The key advantage of maximal levator resection is preservation of muscular structures, such as the Müller's muscle and levator muscle, and supporting structures, such as the levator horns and Whitnall's ligament. As reported by Berke and Wadsworth ${ }^{11}$, the cause of congenital ptosis was dystrophy of the levator muscle. However, they did not observe dystrophy of the Müller's muscle in the same patient group. Thus, unnecessary resection of the Müller's muscle which is an intact and accessory muscle assisting the elevation of the lid was avoided during ptosis surgery. This allows benefiting from the lid-elevating activity of the Müller's muscle. Besides, Müller's muscle provides changes of the level of eyelid via emotions for facial expression ${ }^{12}$. In the present study, in order to avoid damage to the Müller's muscle and conjunctiva, subconjunctival 2\% lidocaine was injected to the palpebral conjunctiva before dissection of the levator aponeurosis from the Müller's muscle and conjunctiva; this provided easier dissection. Segmental dilatation was observed in the upper area of the pupil following the lidocaine injection.

Fatty degeneration and underdevelopment of Whitnall's ligament may be observed in cases with congenital ptosis. In the present study, fatty degeneration and underdevelopment of Whitnall's ligament were observed in the levator muscle intraoperatively in 3 cases as well. Although ideal correction was observed al all cases in the postoperative Week 1, a $1 \mathrm{~mm}$ drooping occurred on the postoperative Month 3. Thus, it can be recommended to perform 
more resection against potential postoperative drooping in cases of congenital ptosis with fatty degeneration and underdevelopment of Whitnall's ligament ${ }^{13}$.

Prior to levatoraponeurosis surgery, it was difficult to obtain consistent results with conventional levator resection. It was not possible to predict the results in advance and also, the success expectations were low. Varying surgical success rates have been achieved by maximal levator resection in the correction of congenital ptosis with poor levator function. Smith et all. ${ }^{14}$ reported the success rate as $73 \%$ in levator resection performed in 148 patients in 1969. They accepted the surgical outcome as successful when the residual ptosis was $2.5 \mathrm{~mm}$ in patients with ptosis of $4 \mathrm{~mm}$. Less improvement was considered sufficient in ptosis surgeries in which classical methods were used. Today, the acknowledged success criterion is complete correction or residual ptosis of $<1 \mathrm{~mm}$ after aponeurosis surgery. In the context of the same criterion, Shore et all. ${ }^{15}$ achieved a success rate of $72.9 \%$ in 37 eyes of congenital myopathic ptosis after external levator resection. Pres and Hübner ${ }^{16}$ performed maximal transcutaneous levator resection in 44 cases of unilateral congenital ptosis with poor levator function and achieved sufficient elevation in 36 cases with $<1 \mathrm{~mm}$ palpebral aperture. Innocentiet all. ${ }^{17}$ reported a surgical success rate of $85 \%$ after external levator muscle complex advancement in patients with bilateral aponeurotic moderate and severe ptosis. In a study by Nguyen and Hardy, ${ }^{18}$ the overall success rate was reported as $86 \%$ following the anterior levator resection in children with congenital ptosis. Sar et all.19 performed four surgical procedures, including levator resection, frontalis suspension, levator advancement, and Fasanella-Servat, for the correction of congenital ptosis in 64 eyes of 57 cases and they reported overall surgical success rate as $76 \%$ after levator resection procedure. Lee et all. ${ }^{10}$ performed maximal levator resection in 243 patients with poor levator function and achieved successful results in $93 \%$ of the patients. In another study by $\mathrm{Wu}$ et all. ${ }^{20}$, levator resection was performed in 84 children who had unilateral congenital ptosis and surgical success rate was reported as 84.5\%. Another study from Iran, Abrishamiet all. ${ }^{21}$ retrospectively reviewed 136 patients with blepharoptosis undergoing levator resection in a 10-year period and reported the surgical success rate after the first operation as $78.3 \%$ for congenital blepharoptosis patients and as $81.3 \%$ for acquired blepharoptosis patients. In a study from Turkey, maximal levator resection surgery 29 eyelids of 23 subjects and successful outcomes were obtained in 14 patients $(71.4 \%)$ and satisfactory outcomes were obtained in two patients (21.4\%).6 In a recent prospective study from Turkey, among 85 ptosis patients, 57 underwent levator aponeurosis procedure and 28 underwent conjunctiva- Müller muscle resection $^{22}$. The authors stated the surgical success rate as $73 \%$ after levator resection and $78 \%$ after conjunctiva- Müller muscle resection. In the present study, maximal levator resection was performed in 33 eyes of 30 congenital myogenic ptosis cases with poor levator function and surgical outcomes were successful in 26 eyes (78\%), satisfactory in 4 eyes, and unsuccessful in 3 eyes.The results of the present study were consistent with the literature.

One of the limitations of the present study was its retrospective design. Another limitation was its sample including both unilateral and bilateral cases. Future prospective studies conducted on homogeneous sample are needed.

In conclusion, successful outcomes were obtained with maximal levator resection performed for congenital ptosis cases with poor levator function. In ptosis surgeries, successful outcomes are achieved with 
methods that do not impair the anatomy, are easy to apply, and provide predictable results. Maximal levator resection can be considered an effective and a safe surgical procedure which is anatomy friendly, has low postoperative complications, is reversible, and allows performing other surgical techniques in case of failure.

Conflicts of interest: The authors have no conflict of interests to declare.

Financial Disclosure: The authors declared that this study has received no financial support.

\section{REFERENCES}

1. Gautam P, Adhikari R, Sharma BR. Etiopathogenetic patterns of blepharoptosis in Western Nepal: an Overview. Nepal J Ophthalmol. 2016; 8: 36-40.

2. Soo Hoo JR, Davies BW, Allard FD, Durairaj VD. Congenital ptosis. Surv Ophthalmol. 2014; 59: 483-92.

3. Finsterer J. Ptosis: causes, presentation, and management.Aesthetic Plast Surg. 2003; 27: 193-204.

4. Marenco M, Macchi I, Macchi I, et all. Clinical presentation and management of congenital ptosis. Clin Ophthalmol. 2017; 11: 453-63.

5. Gazzola R, Piozzi E, Vaienti L, Wilhelm BaruffaldiPreis F. Therapeutic algorithm for congenital ptosis repair with levator resection and frontalis suspension: results and literature review. SeminOphthalmol. 2018; 33: 45460.

6. Mete A, Cagatay HH, Pamukcu C, et all. Maximal levator muscle resection for primary congenital blepharoptosis with poor levator function. Semin Ophthalmol. 2017; 32: 270-75.

7. Goel R, Kishore D, Nagpal S, Jain S, Agarwal T. The relationship of amount of resection and time for recovery of Bell's phenomenon after levator resection in congenital ptosis. Open Ophthalmol J. 2017; 11: 24-30.

8. Bernardini FP, de Conciliis C, Devoto MH. Frontalis suspension sling using a silicone rod in patients affected by myogenic blepharoptosis. Orbit. 2002; 21: 195-8.

9. Lee JH, Kim YD. Surgical treatment of unilateral severe simple congenital ptosis. Taiwan J Ophthalmol. 2018; 8: 3-8.
10. Lee JH, Aryasit O, Kim YD, Woo KI, Lee L, Johnson ON 3rd. Maximal levator resection in unilateral congenital ptosis with poor levator function. Br J Ophthalmol. 2017; 101: 740-46.

11. Berke RN, Wadsworth JA. Histology of levator muscle in congenital and acquired ptosis. AMA Arch Ophthalmol. 1955; 53: 413-28.

12. Collin JR. New concepts in the management of ptosis.Eye (Lond). 1988; 2: 185-8.

13. Ünal M. Levator aponeurosis surgery.T Klin J Ophthalmol. 1997; 6: 98-105.

14. Smith B, McCord CD, Baylis H. Surgical treatment of blepharoptosis. Am J Ophthalmol. 1969; 68: 92-9.

15. Shore JW, Bergin DJ, Garrett SN. Results of blepharoptosis surgery with early postoperative adjustment. Ophthalmology. 1990; 97: 1502-11.

16. Press UP, Hübner H. Maximal levator resection in the treatment of unilateral congenital ptosis with poor levator function.Orbit. 2001; 20: 125-9.

17. Innocenti A, Mori F, Melita D, Dreassi E, Ciancio F, Innocenti $M$. Evaluation of long-term outcomes of correction of severe blepharoptosis with advancement of external levator muscle complex: descriptive statistical analysis of the results. In Vivo. 2017; 31: 111-5.

18. Nguyen CT, Hardy TG. Levator resection for congenital ptosis: Does pre-operative levator function or degree of ptosis affect successful outcome? Orbit. 2017; 36: 325-30.

19. Sar R, Yousuf S, Gupta Y. Surgical management of congenital and aponeurotic ptosis - cosmetic outcome. Austin J Clin Ophthalmol. 2014; 1: 1035.

20. Wu SY, Ma L, Huang HH, Tsai YJ. Analysis of visual outcomes and complications following levator resection for unilateral congenital blepharoptosis without strabismus. Biomed J. 2013; 36: 179-87.

21. Abrishami A, Bagheri A, Salour H, Aletaha M, Yazdani S. Outcomes of levator resection at tertiary eye care center in Iran: a 10-year experience. Korean J Ophthalmol. 2012; 26: 1-5.

22. Şimşek EB, Parlakgüneş S. Results of conjunctiva Müller's muscle resection and external levator resection techniques for ptosis repair ptosis and results of treatment options. OpthClinTher.2018; 2: 9. 